John O Brennan

\title{
GOVERNMENT AND PARLIAMENT
}

\section{INTRODUCTION}

This chapter of Foreign Policy in the Republic of Ireland examines the nature of executive-legislative relations and, more broadly, the policy-making process in the conduct of Irish foreign policy. Amongst other phenomena it analyzes the institutional actors that assert most influence within the foreign policy-making sphere; the nature and intensity of the interaction between the government and Oireachtas in external affairs, the level of engagement of members of the Oireachtas with foreign affairs, including EU affairs; and the opportunity structures for parliamentary scrutiny and oversight of executive action. It goes without saying that no foreign policy can be carried out successfully without being underpinned by an effective governmental machinery. But it is important to understand that the machinery includes not only the core ministries of government and the civil service which support decision-making, but crucially the legitimacy of decision-making will revolve around the ability, willingness and opportunities afforded to parliament to participate in and scrutinize decisions in the foreign affairs sphere.

\section{GOVERNMENT AND FOREIGN POLICY}

The Cabinet or policy-directing body sits at the apex of institutional power within the Irish governmental system. Indeed it may not be going too far to suggest it is the pivot around which all other elements of the political machinery operate. Or as O'Toole and Dooney (2009:3) put it the government constitutes Ireland's 'board of directors: formulating policies, promoting legislation and directing the operations of the various departments of state'. The context here is one of the most highly centralized political systems in Europe characterised by strong central executive control, a subordinate parliament and extremely weak structures of local government. Indeed the level of control wielded by the executive 'is practically unrivalled anywhere else in Europe' (MacCarthaigh, 2005: 217). Executive dominance of the broader political system as we will see applies as much to foreign affairs as it does to purely domestic matters.

In identifying the government as the primary source of authority and decision-making within the foreign affairs arena, we can state that two main functions fall to the Cabinet. In the first place, it is responsible for the initiation and guidance of policy, subject to the watchful but critical control of the Oireachtas; in the second place, it has to ensure an effective co-ordination between the various government departments in the interests of coherent decision-making. If these functions are to be carried out effectively a clear and transparent line of authority is needed. Nevertheless in a comparative context this matrix of responsibilities is both highly centralized and narrowly concentrated. The executive sets the legislative agenda and exerts close control over the timing and passage of bills within the Oireachtas. Indeed such is the absolute level of control by the government that the Taoiseach is viewed as one of the most powerful office holders in Europe (Coakley 2006:113). The government has a wide range of constitutional and legal powers which it has used to assert primacy over 
parliament. Basil Chubb's wry observation (1974:54) that 'the government controls the Dail, instead of, as the Constitution seems to require, the Dail controlling the government' seems even more apparent today than was the case three decades ago. Indeed a number of recent academic studies have demonstrated the extent to which the executive has sought to manipulate existing parliamentary rules to enhance its own power and limit the ability of the parliamentarian to contribute usefully to decision-making. Muiris MacCarthaigh (2005), for example, provides a range of evidence to demonstrate how Dail Standing Orders (DSOs) have been constantly amended 'in a manner that increasingly secured the government's grip on the parliamentary agenda’.

The Taoiseach is the primary officer of the executive - primus inter pares - and sits at the apex of this system of decision-making. As head of government the Taoiseach performs a representational role, in regularly meeting heads of state and government who visit Ireland, and leading Irish diplomatic and trade missions to other countries. He or she will thus enjoy considerable contact with their counterparts in other countries, and quite intense interaction with leaders of EU partner states. The Taoiseach is also the primary decision maker in external affairs, and possesses formal authority sufficient to enable him or her to enjoy both visibility and influence on the international stage. In practice, however, much of the responsibility for Ireland's international activity rests with the Minister for Foreign Affairs. The minister exercises day to day control over the department's policy agenda, leads and has the support of a considerable body of expertise within the civil service and the diplomatic representation, and is the individual responsible to the Oireachtas for policy decisions. So while the Taoiseach is undoubtedly a critical figure in shaping foreign policy, practically speaking institutional power is devolved on a day to day basis to the Minister for Foreign Affairs. The relationship between the Taoiseach and the minister for Foreign Affairs is, however, of central importance to the conduct and efficacy of Ireland's foreign policy.

Irrespective of whether the Taoiseach of the day is a 'chairman' or a 'chief' - to use Brian Farrell's well-worn formulation - how he or she interacts with the Minister for Foreign Affairs will have a crucial bearing on government decision-making. Clearly the kind of approach a 'chairman' might take (encouraging, delegating, cooperating and loosely monitoring) could differ substantially from a more 'Presidential' approach (assertive, interventionist) by a Taoiseach 'as Chief' who might seek to impose his authority on a minister for foreign affairs or seek to use external issues to boost his or her own political profile. In the UK, for example, the Blair years saw an informal move to this type of 'presidentialism' which undermined the relationship between the Prime Minister and his Foreign Secretary (and indeed the position of the Foreign Office within the government). The evidence from Ireland suggests that a much more nuanced and balanced type of relationship between these two senior executive offices has endured.

Given the significant political profiles of the office-holders involved one might expect the system to encourage tension between the Taoiseach and Minister for Foreign Affairs, arising out of intra-party completion within single party governments or interparty competition within coalition formations. The evidence suggests that from time to time Taoisigh have used the Department of Foreign Affairs as a 'dumping ground' for ambitious rivals within their own parties or individuals they suspected they might 
have difficulty working with within a cabinet formation. The rationale here is that responsibility for the foreign affairs portfolio will mean that the office holder will have to spend a large amount of time outside the state, thus making it more difficult to maintain input into and control over vital domestic issues. In theory the Minister for Foreign Affairs should also have less time and scope to deal with internal party political matters: although the post carries considerable prestige and clout within the government being 'exiled' in foreign affairs may make it particularly difficult for an ambitious politician to increase his or her profile and standing within the party at critical junctures where, for example, the leadership of the party may be in play.

In the Fine Gael-Labour coalition in the 1970s, for example, Garret Fitzgerald, Fine Gael's spokesman on finance and the star performer on the opposition benches prior to the 1973 general election, was widely expected to become Minister for Finance in the new coalition government. Instead Taoiseach Liam Cosgrave allocated Dr. Fitzgerald the Department of Foreign Affairs, reasoning that this would weaken his rival's ability to influence domestic debates on socio-economic issues. And whilst this gambit may have succeeded in the short term it also resulted in the unanticipated consequence of turning Fitzgerald into a stellar performer on the European stage and, according to Joe Lee (1989: 475) 'the biggest beneficiary of EEC entry'. As to Cosgrave's motivation Lee outlines the Taoiseach's expectation that Foreign Affairs 'might do a Sean MacBride on Fitzgerald', meaning that Fitzgerald would lose touch with domestic affairs and undermine his own leadership ambitions. That the exact opposite occurred is now readily evident as Fitzgerald imposed himself on his portfolio and in making a success of it ensured he would replace Cosgrave as leader of Fine Gael, and eventually, Taoiseach.

\section{The Minister for Foreign Affairs}

The official understanding of where executive responsibilities lie is laid out in the 1996 White Paper, which states that 'subject to the overall direction of the government, the Minister for Foreign Affairs has responsibility for external political affairs, the coordination of policy in the EU, policy with regard to the UN and other international organizations, development cooperation matters, consular affairs including the issuing of passports, cultural relations, and the operation of foreign service. The minister for Foreign Affairs also has day to day responsibility for policy in relation to Northern Ireland'. The White Paper goes on, however, to point out that other ministers also enjoy an input into policy. These include the ministers for trade, enterprise and employment, tourism, and the Minister for Finance, in respect of external financial policy and the financing of Irish foreign policy. It is clear from this brief description that the division of labour across government is a more plural and complex one, with a greater number of actors and institutional interests than might be suspected. In recent years, for example, as the banking and fiscal crisis of 2008 developed, the relationship between the departments of Finance and Foreign Affairs necessarily became a much closer one with Finance taking on more responsibility than at any time in the history of the state, as it negotiated with the so-called 'troika' of International Monetary Fund (IMF), the European Central Bank (ECB) and the EU (principally but not exclusively the European Commission) on how to re-structure Ireland's burgeoning external debt. The line between the domestic and the international became difficult to distinguish as Ireland's economic sovereignty diminished almost overnight with day to day operational control of the most important external matters being exercised by the Minister for Finance. At the least we can say 
that ordinarily the Minister for Foreign Affairs enjoys considerable latitude for independent action, but is also quite constrained by the contours of a consensual system of executive authority and the complex demands on government of Ireland's international commitments and entanglements.

The process of EU integration discussed further below has also diversified some international affairs away from the Department of Foreign Affairs. Every cabinet minister will attend meetings of the EU's Council of Ministers in their own sector of responsibility and senior officials in every department are likewise involved in an ongoing interaction with their equivalents in other EU member states. While the Department of Foreign Affairs retains a coordinating role for all of this activity, in practice a significant degree of engagement has been devolved to the relevant Minister and their officials.

The Minister for Foreign Affairs holds responsibility for bringing legislative proposals before the cabinet and the Oireachtas, acts as the principal representative of the government within international fora, coordinates all short term emergency actions in response to international crises, and regularly interacts with and is required to report to the Oireachtas Joint Committee on Foreign Affairs and Trade and Joint Committee on European Union Affairs (see next section). In practice the Minister for Foreign Affairs is highly dependent on the Secretary General of the department - the senior civil servant within the administration - who in turn is supported by a Management Advisory Committee (MAC), comprised of heads of division within the department. The Minister is also the office holder who is enjoined to 'speak for Ireland' in the event of an external natural disaster such as the Asian tsunami of 2004 or the New Zealand earthquake of 2011.

In 2011 the new Fine Gael-Labour coalition government decided on a very significant re-calibration of ministerial roles within the government. This led to the addition of the 'trade' portfolio to the work of the Minister for Foreign Affairs. This decision in part came out of analysis of the 2008 economic crash and the subsequent events which so damaged the Irish economy. The entire ministry and the diplomatic representation were effectively reconfigured to emphasize and support the economic and trading dimension of Ireland's external activity and to bring greater coherence to the quest for international recovery. But in part this was simply a reflection of existing practice, as for many years, Ireland's diplomatic representations had been engaged in the promotion of Ireland as a location for inward investment and economic activity. The addition of the trade portfolio to the brief of the Minister for Foreign Affairs also bolstered his position within the ranks of Cabinet.

\section{Ministers of State}

The Minister for Foreign Affairs and Trade is assisted in his role by two ministers of state or junior ministers. These junior posts were introduced as a response to the increased demands on the ministry as Ireland's international engagement deepened quite significantly after the 1960s. Ireland's membership of the European Union, in particular, produced an important organizational change within the ministerial structure. The sheer volume of legislation emanating from Brussels, particularly after the vast extension of so-called 'community' competences stemming from the Single European Act (1987) prompted the institution of a new junior ministry of European affairs, located within the Department of Foreign Affairs. This post was introduced by 
the Government led by Charles Haughey in 1987 and was first held by Máire Geoghean Quinn. Despite some periodic assertions that this post should be one elevated to full cabinet rank it remains subordinate within the ministerial structure to the Minister for Foreign Affairs and Trade. The organizational re-calibration of the department in 2011 left the position and role of the Minister of State for European Affairs virtually unchanged, although responsibility for co-ordination of EU affairs moved to the Department of An Taoiseach, with a second secretary general appointed.

The second significant organizational change followed the extension of Irish engagement with Africa and the developing world, which prompted the creation of a new junior ministry - aid and development. The stated focus of Irish Aid - the brand name given to the programme of Overseas Development and Aid (ODA)- is on 'poverty reduction, with the aim of reducing vulnerability and increasing opportunity for the world's poorest people' (DFA Statement of Strategy 2008-10). Aid and development policy goes beyond the resources and capacities of the DFA and requires a broader governmental focus on coherence of delivery and implementation goals. Working with partner states in and through the United Nations, for example, on the Millennium Development Goals (MDGs) also presents organizational challenges that differ substantially nowadays in both scale and nature from the traditional activities pursued by the department.

The total allocation for Official Development Assistance in 2010 was $€ 671.4$ million, representing approximately $0.5 \%$ of Irish GNP. Ireland is committed to reaching the EU target of spending $0.7 \%$ of GNP on overseas development assistance by 2015 but progress toward this headline goal has slowed considerably with the onset of a deep recession. Nevertheless, given the substantially increased scale of financial commitments associated with the agency over the last decade, one might have expected the further development of this ministerial role. In the United Kingdom, for example, and many other European states, the aid and development portfolio has been separated from the foreign ministry and accorded an importance commensurate with its budget and international visibility. The minister or secretary of state sits at cabinet as a full member of the government. This has not happened in Ireland; the minister responsible for aid and development remains within the Department of Foreign Affairs and Trade and subordinate to the senior minister. The 2011 intra-departmental re-organization changed the focus of the minister of state's role to 'trade and development', but this reflected more a desire to enhance the contribution of the Department of Foreign Affairs to Ireland's economic recovery rather than any substantive intra-departmental organizational logic.

\section{THE OIREACHTAS AND FOREIGN POLICY}

Parliaments are central institutions in modern European systems of government. They elect and control the government, approve legislation, and represent the most important checks on the power of untrammelled executive authority, especially when they exercise functions of oversight and scrutiny. Yet such constitutional perspective is arguably increasingly divorced from reality in both the Irish and international contexts. National parliaments are almost without exception portrayed in the EU literature, for example, as reactive institutions, as 'victims' of the European integration process for one thing, and the broader global context in which foreign policy decision-making has evolved (O’Brennan and Raunio, 2007). Within the Irish political system as we have seen the government's dominance over the legislature is 
clearly apparent. At the very least we can say that the Oireachtas, like other national parliaments in Europe, casts only a rather modest influence on policy initiatives coming from the executive in foreign affairs.

In theory at least the Houses of the Oireachtas exercise an important role in relation to foreign policy; in engaging in plenary debate and providing institutional approval for international treaties and legislation, and in discussing issues of external relations in parliamentary committees and seeking to hold senior office holders to account on foreign policy. Articles 29.5 and 29.6 of Bunreacht na hEireann explicitly set out the power of parliament in the field of international relations. Every international agreement to which the state becomes a party other than those of a technical or administrative character, must be laid before the Dail, and the state cannot be bound by any agreement involving a charge on public funds unless the terms of that agreement have been approved by the Dail. No international agreement may become part of domestic law of the state without the approval of the Oireachtas (White Paper, 1996: 332). Thus a reading of the formal powers enjoyed by the Oireachtas suggests there exists an opportunity structure for TDs and senators to participate actively and purposively in foreign affairs.

The formal institutional division of labour, however, is misleading. In this, as in other areas of policy-making, executive privileges outweigh and prevail over constitutionally-ordained parliamentary prerogatives. Michael Gallagher's recent (2010: 198-229) evaluation of the performance of the Oireachtas noted that with regard to the Dáil it was only a slight exaggeration "to say that all legislation passed by the Dáil emanates from the government, and that all legislation proposed by the government is passed by the Dáil.” This work goes on to describe Dáil debates as "dialogues of the deaf" with little incentive for opposition parties to engage constructively, and concludes that the "Dáil cannot be seen as an active participant in the process of making laws, let alone broader policy" while noting that the Seanad is "by far the weaker of the two houses." (Ibid. 210). There are a number of ways of demonstrating the extent of the relative powerlessness of the Dail in external affairs.

The most important ongoing interaction of the Oireachtas arises through the debate of foreign policy issues and the regular tabling of parliamentary questions by members of the Dail, along with the work of Oireachtas committees. The Dáil holds a major debate on foreign policy annually in relation to its examination of the Estimates for funds to be expended on public services. The lower house also conducts an annual examination of expenditure based on a report of the Comptroller and Auditor General. The Houses of the Oireachtas also hold plenary debates on matters of immediate interest in the foreign affairs sphere. The most important of these is in regard to EU policy and the Taoiseach's report to the Dáil following each meeting of the European Council. Given that the frequency and importance of such EU meetings has increased dramatically over the last decade one might expect the Oireachtas to have instituted more debate and scrutiny of the Taoiseach through the plenary debate forum. But there is little evidence for this in practice. But it is important to note that this is as much because the executive has acted to control and curtail the agenda and rules of procedure pertaining to questioning ministers and government policy, as any indifference or ineffectiveness on the part of Oireachtas members. Neither do such plenary events capture the imagination of the media or the wider public. Thus this avenue of potential parliamentary influence is largely insignificant. 
The second potential vehicle for parliamentary influence is the ability of parliamentarians to table parliamentary questions on any aspects of foreign affairs. The Minister for Foreign Affairs and Trade is the recipient of the vast majority of such questions dealing with foreign policy. However, the more complex modern division of ministerial responsibilities is reflected in the fact that some aspects of EU policy are directed to the sectoral minister holding responsibility in that particular area. As is the case with plenary structures, the executive seems to hold most of the aces. MacCarthaigh's (2005, 2007) observations about the constraining impact on parliament of Dáil Standing Orders (DSOs) apply equally to foreign affairs. For instance, 'oral questions must be submitted three working days in advance, but the TD must wait until it is the relevant minister's day' which allows consultation with civil servants to prepare what is often a sparse statement read into the record of the Dáil by the minister, and more often than not providing obfuscation rather than clarity (Strom, 2003: 431). This demonstrates the extent to which 'Ministers have a multitude of devices to avoid answering questions' (Ibid.). The Ceann Comhairle, who is supposed to be an impartial arbiter between government and parliament, often intervenes and 'rules out of order questions that relate, for example, to internal cabinet discussions' and even where the Ceann Comhairle might have sympathy with the questioner 'the chair has no power to compel the minister to answer a question' (Ibid. 434). One other major obstacle is DSO 86 which allows a minister without any prior notice to preempt private members' time and substitute government business' (Ibid. 431). Thus even the most experienced and skilful operators within the Dáil can find it difficult to get answers to questions on international issues and the chamber itself appears as a powerless ‘talking shop' rather than a robust arena of parliamentary control of executive action.

A third potential avenue of parliamentary influence in decision-making lies in the Committee system. The scope of the Committee system within the Oireachtas has extended significantly since 1970 and the foreign policy arena has been no exception. Parliamentary committees play a potentially vital part in political decision-making, and in many European countries have become almost as influential as individual ministries within policy-making. The Irish committee system, however, despite undeniably improving both its visibility and capacity to act, still finds itself curtailed by executive privilege. In sharp contrast to many European states where legislation is critically examined and adapted at committee stage, in Ireland the decisive plenary stage of a bill precedes the committee stage of deliberation, which means that 'the broad principle has already been politicized and decided' (Strom, 2003: 434). Within the committee system itself the government effectively dominates the terrain through the appointment of chairs and manipulation of the rules of procedure (MacCarthaigh 2005: 103). Unlike Westminster, for example, the Irish government enjoys a 'virtual immunity from informed review or criticism' compared to other countries (Strom 2003: 431). There are a number of reasons for this: the Ceann Comhairle has no power to compel a minister to answer questions; similarly, committees lack powers to compel ministers and civil servants to attend and the constitutional right to absolute cabinet confidentiality also acts as a bulwark against parliamentary oversight (Ibid. 439).

Another significant problem arises from the dominant position of ministers in introducing legislative proposals. MacCarthaigh (2005: 109) observes that in Ireland, (along with the UK and France) while parliament may have in theory a shared right to 
introduce laws, in practice it is very subservient to government. In particular there is very little use of Private Members' Business (PMB), which in the Oireachtas is manipulated so as to benefit the controlling force of government. At just three hours per week the number of hours allocated to PMB is substantially less than in most European jurisdictions (including Westminster), yet even that limited 'window of opportunity' may be adjusted by government 'if it deems it necessary' under DSO 111. In addition government has also created a number of rules which severely limit a parliamentarian's ability to propose PMB, such as DSO 114.1 which states 'to propose PMB a member must be part of a parliamentary group of not fewer than seven members' or DSO 144.4 which states that 'no group can have more than one Bill before the house at any one time' (MacCarthaigh 2005:112-13). This prevents independent TDs and small parties from promoting PMB whiles ensuring that larger opposition parties can only promote one bill at a time. Taken together these procedural rules act as a structural disincentive to any kind of substantive input by parliamentarians into the legislative process: the executive holds a 'lock' over the nature and content of both legislation and scrutiny and exploits every opportunity to consolidate its advantages over parliament.

Recent history is replete with examples of the failure of the Dáil to hold the executive to account in respect of Ireland's international engagement. The controversy over the use of Shannon airport by the US military and whether or not the airport was being used for the purposes of 'extraordinary rendition' of terror suspects exemplified the difficulties of parliamentarians in getting answers from the government. During the 2002-2007 parliamentary term, as the US military campaigns in Afghanistan and Iraq intensified, opposition deputies (especially independents) who sought answers on extraordinary rendition and other issues were frequently stymied by the various procedural biases which favoured government. The Dáil seemed powerless to act on its constitutional function of exercising oversight over government policy, a seeming confirmation of the view expressed by many commentators that the Oireachtas had become an irrelevant sideshow in a system dominated by ministerial privilege.

Against this apparent trend of relative powerlessness it is worth noting that the committee system in the Oireachtas has played another role in recent years, other that its primary one of legislative and government scrutiny. The Joint Committee on Foreign Affairs has provided a platform for NGOs, academics and visiting delegations to interact with legislators on contemporary international issues. This has provided a very useful platform for debate on such issues as climate change, aid and trade, and globalization and provided the committee with a level of research input which it could not secure from its own resources. The greater intensity of both national and international networking around these issues has also been evident and bolstered the Committee's professionalism and capacity for independent initiative. It does raise some issues about the committee's technical ability to assess the information provided to it, as the level of staffing for the committee means it can only relay on officials in the Department of Foreign Affairs and Trade, whose primary line of responsibility is one of course to the Minister of the day. If the Committee is debating the merits of Irish Government policy on a particular issue brought to their attention by an NGO or visiting delegation they have no access to expertise which is fully independent of the Minister and the Government. And whilst the Irish committee system generally remains substantially under-resourced compared to international partner states, some identifiable improvements have taken place over the last decade which have enabled 
the Joint Committee on Foreign Affairs to play at least a more visible role than was previously the case.

The reason for the relative weakness of the Irish parliament is obviously a debate that goes well beyond foreign policy. There is little agreement, even among specialists as to which are the most significant explanatory factors. Issues which are commonly pointed to include the relatively clientelist nature of Irish politics and the strong party discipline pertaining within Irish political parties. Both of these act as structural disincentives toward active parliamentary engagement with foreign policy issues. But the causal impact of these factors are also contested with different explanations looking for example to the electoral system and specific elements of Irish political culture. What we can say is that in a comparative context Ireland represents a readily identifiable case of a foreign policy system dominated by government actors and one where parliament signally fails to fulfil its constitutional mandate of holding the government to account.

\section{THE EUROPEAN UNION AND 'EUROPEANIZATION'}

Membership of the European Economic Community (EEC) in 1973 had a transformative effect on the country, and not surprisingly on the actors, identities and institutions of foreign policy-making in Ireland. Even in the early days of membership it was already evident, as Patrick Keatinge argued (1978: 210) that membership had transformed the role of the Department of Foreign Affairs. The 'European' layer of governance in Ireland has, over time, become a domestic layer as the boundaries of what previously were thought of as discrete national and supranational areas of competence have gradually dissolved. 'Europeanization', in different forms and via a multitude of routes, has played a decisive part in shaping Irish foreign policy over almost four decades of membership.

Europeanization was defined originally by Robert Ladrech (1994: 32) as 'an incremental process reorienting the direction and shape of politics to the degree that EC [European Community] political and economic dynamics become part of the organizational logic of national politics and policy-making.' 'Europeanization' is hence primarily a top-down concept, employed for analysing the impact of European integration on developments at the national level... The EU creates new exit, veto, and informational opportunities for domestic actors and therefore changes the national opportunity structure for exerting political influence. The idea is thus simple: states are not homogeneous, monolithic entities and the process of European integration may empower certain groups or institutions while reducing the power of others.

Academic studies have also suggested that Europeanization has re-inforced the existing dominance of decision-making by executive actors, leading to a phenomenon known as 'deparliamentarization'. National parliaments are almost without exception portrayed in the literature as reactive institutions, as 'victims' of the European integration process, rather than purposive independent actors (O'Brennan and Raunio 2007). According to the 'deparliamentarization' thesis, the development of European integration has led to an erosion (or further erosion) of parliamentary control over executive office-holders. This argument is based both on EU constitutional rules and on the political dynamics of the policy process at EU level. Constitutionally, the issue is relatively straightforward. Powers which previously were under the jurisdiction of 
national legislatures have been shifted upwards to the European level and the European Council has become a more powerful actor than ever envisaged: a marked trend toward 'intergovermentalism' within the EU has rewarded executive actors at the expense of domestic parliaments and national agency.

Europeanisation of foreign policy takes place on a number of levels and through multiple interactions in national capitals and in Brussels. At its most formal EU member states seek to agree common foreign policies or at least adopt common positions on international issues, as discussed in more detail in chapter XXX. Irish foreign policy also seeks to influence decisions inside the EU and has over time taken on a stronger and more pronounced EU focus in that regard. However it would be a mistake to see the process of europeanistion as a process whereby 27 member states arrive in Brussels to negotiate a common position, from a starting point of 27 different (and potentially conflicting) policies. No major policy is now developed in any member state without taking account of the EU dimension during the national decision making process. National policies are therefore always impacted by a process of Europeanisation even before inter-governmental negotiations take place. The member states of the EU have effectively been socialized into adopting a kind of collective consciousness even if there remains plenty of scope for independent (national) action. This collectivism remains contested and partial but forms the basis for the more robust EU approach to international affairs inherent in the Common Security and Defence Policy.

Research on the impact of the EU on national politics has also provided strong support to the deparliamentarization thesis. Rometsch and Wessels (1996) uncovered certain similarities between the member states: the strengthening of the position of the prime minister, the central role of executive authority coupled with decentralization and flexibility in decision-making, the bureaucratization of public policy-making, high administrative coordination in national EU policy, and, significantly, low involvement of national parliaments. The follow-up volume edited by Wessels, Maurer and Mittag (2003) largely confirmed these findings. Despite some improvement, they concluded on a pessimistic note that 'continuous deficits in parliaments' ability to play the multi-level game reduce the influence of national deputies. The involvement of parliaments in the EU policy-cycle remains weak and largely reactive.' (Ibid.: 433) Summing up the role of national parliaments in this policy coordination, Kassim (2000: 258) observed that parliaments have 'very little ability to scrutinize Union proposals, still less to influence their content, and are able only in very exceptional cases to direct the actions of their respective governments.' Country-specific accounts of Europeanization largely confirm the findings of these comparative projects (O’Brennan and and Raunio 2007). More recently the protracted economic crisis which unfolded after 2008 further cemented the authority of governments as the central actors within the Eurozone in particular.

The Irish case seems to wholly confirm these findings: patterns of Europeanisation leading to a strengthening of the executive and a reduced role for the Oireachtas in EU affairs. More broadly the pattern of domestic institutional change set in train by Europeanisation has been described as 'pragmatic adaptation' (Connaughton, 2009; Rees, Quinn and Connaughton, 2006) and, in a slight variation of the theme, 'gradual incremental adjustment' (Laffan and O' Mahoney, 2007). The 'Europeanization' of Irish public policy has been managed from the centre, by what has been termed the 
'Holy Trinity' of Irish government - the Department of Foreign Affairs, the Department of Finance and the Department of An Taoiseach (Laffan and O' Mahony, 2008: 64). From the earliest days of membership the day-to-day business of managing Ireland's relations with Brussels fell to Foreign Affairs, which relied to a great extent on the Irish Permanent Representation in Brussels. Over time we have seen a subtle re-balancing of responsibilities between Foreign Affairs and Finance, which, from the beginning of formal statehood in 1922, had been the pre-eminent government department. The twin processes of deepening and widening of the EU triggered a significant change within the relationship between the two departments, with DFA taking on more responsibility (and status).

More recently, in keeping with the trend toward 're-inforced intergovernmentalism' as the defining mode of interaction at EU level, the Department of an Taoiseach has taken on a much more prominent role, confirmed by the transfer of administrative responsibility for European affairs to that department in June 2011, with a second secretary general appointed.. A new EU division was created consisting of a merger of personnel drawn from the EU and international division of the Department of An Taoiseach and from the EU affairs division of the Department of Foreign Affairs and Trade. The move would see about 30 people transferring from the latter to the new structure. In an internal memo explaining the changes Secretary General David Cooney noted that the new arrangements responded to "the evolution of EU institutional arrangements and practices" in the wake of the Lisbon Treaty. He said that the measures also responded to the need to ensure "stronger co-ordination and strategic direction of Ireland's engagement with the EU" across the whole of Government. "It has long been recognised in this department that the necessary level of co-ordination can only be driven from within the Department of the Taoiseach," he added. Clearly this important change will take time to bed down and new patterns may emerge in both the inter-departmental constellation and the relationship between government and parliament as a result. What seems clear, however, is that the reconfiguration represents the latest stage in a series which have considerably boosted the power of the Department of An Taoiseach in EU affairs.

The Oireachtas first established a system of Community legislation scrutiny in 1973 and this work was later subsumed by the first Joint Committee on Foreign Affairs in 1993. However, in March 1995 the Oireachtas set up a separate Joint Committee on European Affairs (JCEA) which subsumed the JCSLEC. The most important subsequent changes occurred after the Nice Referendum defeat in 2001, which some see as a watershed moment in Ireland's relationship with the European Union (O’Brennan, 2004, 2009, 2010). The European Union (Scrutiny) Act of 2002 laid down the legislative basis for parliamentary scrutiny of EU legislative proposals in the Houses of the Oireachtas. Under the Act the Government is legally obliged to lay copies of all EU legislative proposals before both Houses of the Oireachtas together with a statement of the Minister outlining the content, purpose and likely implications for Ireland of the proposed measure. In 2007 the Houses of the Oireachtas established a Joint Committee on European Scrutiny. The Committee fulfills its role within the framework of the European Union (Scrutiny) Act by carrying out detailed scrutiny of EU legislatives proposals on behalf of the Parliament and reports on the implications of the proposals, setting out its conclusions and any recommendations, to both Houses of the Oireachtas. An important feature of the EU Scrutiny system is the power of the Houses of the Oireachtas or a Parliamentary Committee to make recommendations to 
Ministers in relation to EU proposals which ministers are legally obliged to take into consideration. Ben Tonra's (2008) examination of parliamentary oversight of Common Foreign and Security Policy highlights how in plenary session in the Dáil and Seanad through questioning and debates, senators and TDs are able to exercise at least some levels of oversight in this area. In addition, he notes how CFSP issues are raised through the JCFA, the JCEA and the JCES. While he would appear to be doubtful of the ability of parliamentarians to exercise clear influence, he does provide evidence of considerable parliamentary activity in those areas.

Whilst these innovations should be considered positively, Gavin Barrett (2008) maintains a note of caution, and suggests that while the various measures brought in through the European Union (Scrutiny) Act, 2002 were a clear improvement on the previous experience and are 'undoubtedly welcome, their effectiveness in securing executive accountability remains open to doubt. There is a vast difference between 'making recommendations' to ministers and having the power to change or at least substantially influence government policy.

Clearly the role of individual TDs and the collective input of the Oireachtas into EU decision-making can only be understood with reference to the structures of domestic as well as EU decision-making. Here the interplay between the effects of clientelism, the manipulation of parliamentary rules of procedure by government, and the enduring weakness of Irish parliamentary structures are re-enforced by EU effects which further encourage top-down centralization and bureaucratic management of policy, in the name of coherent and effective implementation of EU policy (O’Brennan,2009). But understanding the role of the Oireachtas (and of individual members of parliament) in EU decision-making seems particularly compelling in the light of the rejection of EU-related referendums in 2001 and 2008. Although it is frequently alleged that the failure of the referendums can be attributed to a so-called 'democratic deficit' at EU level, there exists a much more important domestic democratic deficit in that the political representatives charged with the responsibility of holding executive authority to account seem disengaged from the European integration process and unable or unwilling to properly scrutinise Irish governmental action in the EU sphere. Members of the Oireachtas did not campaign forcefully for the Lisbon Treaty in 2008 and many of them appeared distinctly uncomfortable when making public appearances or media interviews. The impression given was of a parliament which is uninformed, unimportant, remote from the policy-making process and essentially voiceless: 'communicating Europe' has become a thankless and unwelcome (if indeed fitfully periodic) task for mainstream political representatives rooted in a robustly localist political culture and who themselves have both little opportunity to influence EU policy-making and little to gain from engaging seriously with EU affairs (O’Brennan, 2009)

\section{CONCLUSION}

The relationship between government and parliament is critical to political decisionmaking and the legitimacy of politics. Ireland's highly centralized political system characterized by a strong central executive and a relatively weak parliament means that parliamentary scrutiny of government action on foreign policy, as in all other areas is relatively weak by international standards. Executive dominance has been a feature of the system from its earliest days in the 1920s but has became 'locked in' 
over time, in particular, by rules of procedure which limit the ability of the Dail to engage in any meaningful agenda setting or oversight roles and by a style of politics which prioritises a constituency focus over parliamentary activity.

Ireland's membership of the EU and the patterns of 'Europeanization' which have occurred in recent decades has re-inforced these existing tendencies toward governmental control of foreign policy. EU policy-making has been overseen by a combination of the departments of Foreign Affairs, Finance and An Taoiseach, assisted by a highly effective civil service. There has been little or no room for the Oireachtas to assert itself, whether in the early stages of policy initiation or the later stages of implementation. All these unhealthy features, taken together, demonstrate that the executive acts as the master of parliament, not as its agent, as the Westminster system implies. Cabinet ministers rarely take the Oireachtas seriously, or at least seriously enough. The Irish system of foreign policy decision-making may demonstrate institutional coherence and certainly allows the country to 'punch above its weight' in the international arena, but it demonstrably fails to engage parliamentarians or allows them to adequately discharge the important functions of oversight and scrutiny of government action which the constitution requires.

Further Reading

Laffan, B and J. O’Mahony, Ireland and the European Union, Basingstoke, Palgrave, 2008.

Rees,N., Quinn,B. and Connaughton, B., (eds) (2009) Europeanisation and New Patterns of Governance in Ireland. Manchester: Manchester University Press.

O'Brennan, J., 2010. 'Ireland and the European Union: Modes of Adaptation and Contestation', in John Hogan (ed.) Ireland: Business and Society, Dublin: Gill and MacMillan, pp.379-97.

J. O’Brennan, 'Ireland's National Forum on Europe: Elite Deliberation meets Popular Participation', Journal of European Integration, Volume 26, Number 2, 2004, pp.167182.

\section{BIBLIOGRAPHY}

Barrett, Gavin (Ed), 2008, National Parliaments and the European Union: The Constitutional Challenge for the Oireachtas and Other Member State Legislatures, Dublin: Clarus Press

Coakley J., (2006),

DFA Statement of Strategy 2008-10

Gallagher, Michael, 2010, 'The Oireachtas: President and parliament” in Coakley, John and Michael Gallagher (eds), Politics in the Republic of Ireland, $5^{\text {th }}$ Edition, Dublin: Routledge, pp.198-229 
Keatinge, P. (1978) A Place among the Nations (Dublin)

Laderach, Robert 1994 Europeanization of Domestic Politics and Institutions: the case of France, Journal of Common Market Studies, Volume 32,Number 1,

Laffan, B and J. O’Mahony, Ireland and the European Union, Basingstoke, Palgrave, 2008.

Laffan, Brigid, 2005, 'Ireland's management of EU business: the impact of Nice' in Michael Holmes (ed), Ireland and the European Union: Nice, Enlargement and the Future of Europe, Manchester: Manchester University Press, pp.171-188

Lee,J.J.,(1989) Ireland 1912-1965: Politics and Society, Cambridge: Cambridge University Press.

MacCarthaigh, M. (2005) Accountability in Irish Parliamentary Politics, Dublin: Institute of Public Administration.

MacCarthaigh, M \& Hayward, K. (2007) Recycling the State: The politics of adaptation in Ireland. Dublin, Irish Academic Press

O’Brennan, J., 2010. 'Ireland and the European Union: Modes of Adaptation and Contestation', in John Hogan (ed.) Ireland: Business and Society, Dublin: Gill and MacMillan, pp.379-97.

O' Brennan, J., 2009. 'Ireland says No (again): the 12 June 2008 Referendum on the Lisbon Treaty', Parliamentary Affairs, Volume 62, Number 2, April, pp.258-77.

J. O’Brennan, 'The National Forum on Europe', in M. Holmes (ed.) Ireland and the European Union Post-Nice, Manchester: Manchester University Press, 2005, pp.114132.

O’Brennan and Raunio (2007) National Parliaments within the Enlarged European Union: from 'Victims' of Integration to Competitive Actors? Abingdon: Routledge.

O’ Toole,J. and Dooney, S.,(2009), Irish Government Today, third edition, Dublin: Gill and MacMillan.

Rometsch and Wessels (1996) The European Union and Member States: towards institutional fusion? Manchester, Manchester University Press.

Wessels Maurer and Mittag (2003) Fifteen into One? The European Union and its Member States

Kassim (2000) 
Strom, K. W. Muller and T. Bergman (2003) Delegation and Accountability in Parliamentary Democracies, Oxford: Oxford University Press.

Tonra, B. (2006) Global Citizen and European Republic: Irish Foreign Policy in Transition, Manchester, Manchester University Press. 